\title{
New Drug Formulations and Their Respective Generic Entry Dates
}

\author{
Reed F. Beall, PhD; Aaron S. Kesselheim, MD, JD, MPH; and Ameet Sarpatwari, JD, PhD
}

\begin{abstract}
BACKGROUND: After new prescription drugs reach the market, manufacturers sometimes create modified versions of them. These new formulations can expand patient treatment options, but they may also be protected by later-expiring patents or data exclusivities, which can lead to later generic entry for the new formulations compared with the original product.

OBJECTIVE: To quantify how frequently manufacturers introduce new formulations of existing drugs and how often these new formulations earn additional years of market exclusivity beyond that of the original product.

METHODS: Using a cohort design and FDA databases, we assessed how frequently manufacturers introduced new formulations of 17 new smallmolecule drugs approved in 2002 and when generic entry for the new formulations and original product occurred.
\end{abstract}

RESULTS: Through 2017, nine (53\%) drugs approved in 2002 had been connected to 21 new formulations, most (11/21, 53\%) introduced before 2007. Generic entry was observed in 6 of $9(67 \%)$ cases and occurred more than 2 years later for the new formulations in 3 of the cases.

CONCLUSIONS: Our results suggest that the introduction of new formulations of brand-name drugs occurs in about half of cases and sometimes provides manufacturers with a lengthy period of additional market exclusivity beyond that of the original product.

J Manag Care Spec Pharm. 2019;25(2):218-24

Copyright $\odot 2019$, Academy of Managed Care Pharmacy. All rights reserved.

\section{What is already known about this subject}

Manufacturers sometimes introduce different versions of previously approved drugs.

Previous studies have described specific cases in which manufacturers have gained additional years of market exclusivity beyond that of the original product through such action.

\section{What this study adds}

This systematic investigation found that manufacturers introduce new formulations of small-molecule drugs in about half of cases. Among half of cases in which a new formulation was introduced and generic entry occurred, manufacturers gained more than 2 years of additional market exclusivity relative to the original product.
B rand-name drug manufacturers sometimes create modified versions of their approved drugs, such as new strengths, dosage forms, and routes of delivery. Some of these products meaningfully expand patient treatment options. For example, United Therapeutics introduced the pulmonary arterial hypertension treatment treprostinil as an intravenous infusion (Remodulin) in 2002, as an inhaled formulation (Tyvaso) in 2009, and as an oral tablet (Orenitram) in 2013, providing other routes of administration that may be more convenient for certain patients.

However, other cases of brand-name product modification have come under scrutiny for offering no clear therapeutic advantages. ${ }^{1-3}$ Facing loss of exclusivity on its $67 \mathrm{mg}, 134 \mathrm{mg}$, and $200 \mathrm{mg}$ capsule versions of the lipid-lowering drug fenofibrate (Tricor), Abbott introduced $54 \mathrm{mg}, 160 \mathrm{mg}$, and $200 \mathrm{mg}$ tablet formulations of the drug in 2001. These new formulations "had no demonstrated incremental benefit on surrogate or patient outcomes" but generated more than $\$ 9$ million in sales for the company over the next 8 years.

This latter set of activities is one type of "product hopping" and can help manufacturers prolong revenue streams relating to the underlying active ingredients of drugs. ${ }^{4-6} \mathrm{New}$ formulations of products may be protected by patents, and all receive a 3-year "new clinical investigation" regulatory exclusivity by the Hatch-Waxman Act, which prevents generic versions of the product from being approved by the U.S. Food and Drug Administration (FDA). ${ }^{7}$ Complementary business strategies, such as product discontinuation, can augment the effect of product hopping. For example, in 2015, the brand-name manufacturer of memantine (Namenda), an Alzheimer's disease treatment, introduced an extended-release formulation (Namenda XR) and tried to discontinue the original version a few months before generic versions of it would have been available. This "hard switch" would have forced patients who had been taking brand-name memantine onto brand-name, extended-release memantine but was averted by a lawsuit filed by the New York Attorney General. ${ }^{8}$

While previous studies have described specific cases of product hopping, ${ }^{9-13}$ none have systematically examined its prevalence. In this study, we sought to assess how often manufacturers introduce new formulations of approved products and when generic entry for those new formulations occurs.

\section{Methods}

\section{Study Design and Cohort Selection}

Using Drugs@FDA, a publicly available online database, we retrospectively traced modified versions (new formulation products) of new small-molecule drugs first approved in 2002 (reference products) that manufacturers introduced over the following 15 years. The year 2002 was chosen to account for the average market exclusivity for new drugs: between 12 and 14 years. ${ }^{14-16}$ We chose not to study biologic drugs approved that year because biologic drugs only recently faced the 
prospect of biosimilar competition and because the dynamics of such competition are substantially different than those of generic competition. ${ }^{17}$ This study did not involve human subjects research and was thus exempt from institutional review board review.

\section{Identification of New Formulation Products, Indications, Generic Entry, and Product Discontinuations}

Using archived (2002-2016) and current versions of the "Approved Drug Products with Therapeutic Equivalence Evaluations," commonly known as the Orange Book (2017) - a publication containing descriptive information on all FDAapproved drugs, including their active ingredient, strength, dosage form, route of administration, approval date, marketing status, manufacturer, and exclusivities-we extracted brandname products with the same active ingredients and manufacturer as a reference product but with later approval dates and different strengths, dosage forms, co-formulations, or routes of administration. ${ }^{18,19}$ We defined each reference product and its new formulation products as a product portfolio and extracted the date of generic entry for these products from Drugs@FDA.

For discontinued products, we isolated the year of discontinuation based on the year it first appeared in the Orange Book's discontinuations table. When generic manufacturers seek to market versions of brand-name drugs that have been discontinued, they must petition the FDA to confirm that the product's discontinuation was a voluntary business decision and was not done for safety or efficacy reasons. The FDA indicates its finding that a drug was voluntarily discontinued in the Federal Register, which served as another data source for our investigation.

\section{Regulatory and Patent Exclusivities}

We also extracted from the Orange Book the expiration dates of applicable market regulatory exclusivities granted by the FDA. ${ }^{20}$ Upon approval by the FDA, new drugs receive a 5-year new chemical entity (NCE) regulatory exclusivity, which-like the 3-year new formulation regulatory exclusivity-prevents generic versions of the product from entering the market. In addition, drugs approved for the treatment of rare diseases are eligible for a 7-year orphan drug regulatory exclusivity that bars the FDA from approving generic applications for the same indication.

For identification of key patents, we searched the U.S. Patent and Trade Office's database for products that were granted patent term restoration, ${ }^{21}$ an extension offered to drug manufacturers to account for patent time lost during clinical testing and FDA review (up to 5 years). Companies typically choose to apply patent term restoration to the key patent covering the active ingredient, since this is often the first patent on the product and the most effective at blocking generic competition. ${ }^{22,23}$ To obtain the expiration date of this patent, we consulted the Orange Book. If patent term restoration was not found, we used the earliest patent listed in the Orange Book. ${ }^{24}$

\section{Analysis}

We reported descriptive statistics on the number and type (new strength, dosage form, route of administration, or co-formulation) of new formulation products that entered the market. We further reported the timing of new formulation product entry relative to the expiration of regulatory exclusivity and the key patent.

To measure market exclusivity periods within and across the product portfolios, we coded new formulation products by the order in which they were introduced to a portfolio (e.g., first, second, and third) and tabulated the number of years between FDA approval and generic entry for each reference and new formulation product until the end of the observation period. Mean and median times were reported.

Finally, to examine relationships between generic entry and the introduction (and discontinuation, if any) of new formulation products relative to the expiration of their exclusivities, we created lineage maps for each product portfolio that charted when reference and new formulation products were introduced (and discontinued, where relevant), when underlying key exclusivities expired, and when each product in the portfolio experienced generic entry.

\section{Results}

Seventeen new drugs that were approved in 2002 met our inclusion criteria. They were indicated for a range of conditions, including central nervous system $(n=4)$ and cardiovascular $(n=3)$ diseases. By 2017, nine $(53 \%)$ had experienced generic competition. Among the 17 reference products, 9 (53\%) were linked to 21 new formulation products (Table 1), an average of 1.4 (median $=1$, interquartile range $[\mathrm{IQR}]=0-2$ ) new formulation products per reference product. These 21 new formulation products included new dosage forms (3, 15\%), strengths $(5,24 \%)$, co-formulations $(5,24 \%)$, or combinations of these modifications (8, 40\%).

\section{Introduction of New Formulation Products}

Eleven (52\%) new formulation products were introduced during the first 5 years of the study period (i.e., during the NCE exclusivity period), 3 (14\%) over the following 5 years, and 7 (33\%) in the final 5 years of the study period. With 1 exception (sodium oxybate), the key patent for each reference product expired during the study period, an average of 11.7 years (median $=12.4, \mathrm{IQR}=10.8-14.5$ ) after FDA approval. New formulation products of 2 reference products-aripiprazole and treprostinil-were approved less than 2 years before key patent expiration. All other new formulation products were introduced more than 2 years before key patent expiration.

\section{Generic Entry}

Generic entry for the reference products $(n=17)$ occurred an average of 12.2 years (median $=14.5, \mathrm{IQR}=9.4-14.7$ ) after their approval. By contrast, generic entry for first new formulation products $(n=9)$ occurred an average of 8.8 years (median=10.0, IQR=5.6-12.8) after their approval; for second new formulation products $(n=7)$ an average of 6.5 years (median=8.9, IQR=3.8-9.3) after their approval; and for third new formulation products $(n=3)$ an average of 6.0 years (median=6.3, IQR=3.5-8.6; Figure 1). The remaining new formulation products were aripiprazole's fourth and fifth set of new formulation products, which had accumulated 4.4 and 2.8 years of exclusivity by the end of the study period. The average market exclusivity garnered by new formulation products beyond the time of generic entry for their respective reference 


\section{TABLE 1 Reference and New Formulation Products in Cohort, Listed by Product Portfolio}

\begin{tabular}{|c|c|c|c|c|c|c|c|c|}
\hline $\begin{array}{l}\text { Drug } \\
\text { Portfolio } \\
\end{array}$ & $\begin{array}{c}\text { Original } \\
\text { Indication }^{\mathrm{a}}\end{array}$ & Product Category & Approval & $\begin{array}{l}\text { Product Change } \\
\text { Category }\end{array}$ & $\begin{array}{c}\text { Product } \\
\text { Characteristics }\end{array}$ & Discontinued & $\begin{array}{l}\text { Key Patent } \\
\text { Expiration } \\
\end{array}$ & $\begin{array}{c}\text { Date of First } \\
\text { Generic } \\
\text { Entry } \\
\end{array}$ \\
\hline \multirow{6}{*}{$\begin{array}{l}\text { Aripiprazole } \\
\text { (Abilify) }\end{array}$} & \multirow[t]{6}{*}{ Schizophrenia } & Reference & $11 / 15 / 2002$ & N/A & Tablet & & $04 / 20 / 2015$ & $04 / 28 / 2015$ \\
\hline & & $\begin{array}{l}\text { New formulation } \\
\text { \#1 }\end{array}$ & $12 / 10 / 2004$ & $\begin{array}{l}\text { New dosage form, } \\
\text { strength }\end{array}$ & Solution, $1 \mathrm{mg} / \mathrm{ml}$ & $2015^{b}$ & & $08 / 14 / 2015$ \\
\hline & & $\begin{array}{l}\text { New formulation } \\
\quad \# 2\end{array}$ & $06 / 07 / 2006$ & New dosage form & $\begin{array}{l}\text { Tablet, orally } \\
\text { disintegrating }\end{array}$ & $\begin{array}{l}2008^{\mathrm{b}} \\
2016^{\mathrm{b}}\end{array}$ & & $04 / 28 / 2015$ \\
\hline & & $\begin{array}{l}\text { New formulation } \\
\# 3\end{array}$ & 09/20/2006 & $\begin{array}{l}\text { New dosage form, } \\
\text { route, strength }\end{array}$ & $\begin{array}{c}\text { Injectable, } \\
\text { intramuscular, } \\
9.75 \mathrm{mg} / 1.3 \mathrm{ml}\end{array}$ & 2016 & & None \\
\hline & & $\begin{array}{l}\text { New formulation } \\
\quad \# 4\end{array}$ & $02 / 28 / 2013$ & $\begin{array}{l}\text { New dosage form, } \\
\text { strength }\end{array}$ & $\begin{array}{l}\text { Suspension, extended } \\
\text { release, } 300 \mathrm{mg} / \mathrm{vial} \text {, } \\
400 \mathrm{mg} / \mathrm{vial}\end{array}$ & & & None \\
\hline & & $\begin{array}{l}\text { New formulation } \\
\quad \# 5\end{array}$ & 09/29/2014 & New strength & $\begin{array}{l}\text { Suspension, extended } \\
\text { release, } 300 \mathrm{mg}, \\
400 \mathrm{mg}\end{array}$ & & & None \\
\hline \multirow{2}{*}{$\begin{array}{l}\text { Atomoxetine } \\
\text { (Strattera) }\end{array}$} & \multirow{2}{*}{$\begin{array}{l}\text { Attention-deficit/ } \\
\text { hyperactivity dis- } \\
\text { order }\end{array}$} & Reference & $11 / 26 / 2002$ & N/A & Capsule & & $05 / 26 / 2017$ & $09 / 17 / 2010$ \\
\hline & & $\begin{array}{c}\text { New formulation } \\
\# 1\end{array}$ & $02 / 14 / 2005$ & New strength & $\begin{array}{c}\text { Capsule, } 80 \mathrm{mg} \\
100 \mathrm{mg}\end{array}$ & & & 09/17/2010 \\
\hline \multirow{3}{*}{$\begin{array}{l}\text { Ezetimibe } \\
\text { (Zetia) }\end{array}$} & \multirow{3}{*}{$\begin{array}{l}\text { Hypercholes- } \\
\text { terolemia }\end{array}$} & Reference & $10 / 25 / 2002$ & N/A & Tablet & & $04 / 25 / 2017$ & $06 / 26 / 2015$ \\
\hline & & $\begin{array}{c}\text { New formulation } \\
\# 1\end{array}$ & $07 / 23 / 2004$ & New co-formulation & $\begin{array}{l}\text { Combined with } \\
\text { simvastatin }\end{array}$ & & & $04 / 26 / 2017$ \\
\hline & & $\begin{array}{l}\text { New formulation } \\
\quad \# 2\end{array}$ & 05/03/2013 & New co-formulation & $\begin{array}{l}\text { Combined with } \\
\text { atorvastatin }\end{array}$ & $2017^{b}$ & & $04 / 26 / 2017$ \\
\hline \multirow{2}{*}{$\begin{array}{l}\text { Nitazoxanide } \\
\text { (Alinia) }\end{array}$} & \multirow{2}{*}{$\begin{array}{l}\text { Parasitic } \\
\text { infections }\end{array}$} & Reference & $11 / 22 / 2002$ & N/A & Suspension & & $09 / 08 / 2014$ & None \\
\hline & & $\begin{array}{c}\text { New formulation } \\
\# 1\end{array}$ & $07 / 21 / 2004$ & New dosage form & Tablet & & & None \\
\hline \multirow{3}{*}{$\begin{array}{l}\text { Nitisinone } \\
\text { (Orfadin) }\end{array}$} & \multirow{3}{*}{$\begin{array}{l}\text { Hereditary } \\
\text { tyrosinemia } \\
\text { type } 1\end{array}$} & Reference & $01 / 18 / 2002$ & N/A & Capsule & & $04 / 09 / 2008$ & None \\
\hline & & $\begin{array}{l}\text { New formulation } \\
\# 1\end{array}$ & $04 / 22 / 2016$ & $\begin{array}{l}\text { New dosage form, } \\
\text { strength }\end{array}$ & $\begin{array}{l}\text { Suspension, } \\
4 \mathrm{mg} / \mathrm{ml}\end{array}$ & & & None \\
\hline & & $\begin{array}{l}\text { New formulation } \\
\quad \# 2\end{array}$ & $06 / 13 / 2016$ & New strength & Capsule, $20 \mathrm{mg}$ & & & None \\
\hline \multirow{4}{*}{$\begin{array}{l}\text { Olmesartan } \\
\text { (Benicar) }\end{array}$} & \multirow[t]{4}{*}{ Hypertension } & Reference & $04 / 25 / 2002$ & N/A & Tablet & & $10 / 25 / 2016$ & $10 / 26 / 2016$ \\
\hline & & $\begin{array}{c}\text { New formulation } \\
\# 1\end{array}$ & $06 / 05 / 2003$ & New co-formulation & $\begin{array}{c}\text { Combined with } \\
\text { hydrochlorothiazide }\end{array}$ & & & $10 / 26 / 2016$ \\
\hline & & $\begin{array}{l}\text { New formulation } \\
\quad \# 2\end{array}$ & $09 / 26 / 2007$ & New co-formulation & $\begin{array}{l}\text { Combined with } \\
\text { amlodipine }\end{array}$ & & & $10 / 26 / 2016$ \\
\hline & & $\begin{array}{l}\text { New formulation } \\
\# 3\end{array}$ & $07 / 23 / 2010$ & New co-formulation & $\begin{array}{c}\text { Combined with } \\
\text { amlodipine and } \\
\text { hydrochlorothiazide }\end{array}$ & & & $10 / 26 / 2016$ \\
\hline \multirow{3}{*}{$\begin{array}{l}\text { Oxaliplatin } \\
\text { (Eloxatin) }\end{array}$} & \multirow[t]{3}{*}{ Colon cancer } & Reference & $08 / 09 / 2002$ & N/A & Injectable, IV & $2006^{b}$ & $02 / 09 / 2017$ & $08 / 07 / 2009$ \\
\hline & & $\begin{array}{l}\text { New formulation } \\
\quad \# 1\end{array}$ & $01 / 31 / 2005$ & $\begin{array}{l}\text { New dosage form, } \\
\text { strength }\end{array}$ & $\begin{array}{l}\text { Injectable, } 50 \mathrm{mg} / \\
10 \mathrm{mg}, 100 \mathrm{mg} / 20 \mathrm{ml}\end{array}$ & & & 08/07/2009 \\
\hline & & $\begin{array}{l}\text { New formulation } \\
\quad \# 2\end{array}$ & $11 / 17 / 2006$ & New strength & $\begin{array}{c}\text { Injectable, } \\
200 \mathrm{mg} / 40 \mathrm{ml}\end{array}$ & $2016^{b}$ & & 07/06/2016 \\
\hline \multirow{4}{*}{$\begin{array}{l}\text { Treprostinil } \\
\text { (Remodulin) }\end{array}$} & \multirow[t]{4}{*}{ Hypertension } & Reference & $05 / 21 / 2002$ & N/A & Injectable, IV & & $10 / 06 / 2014$ & None \\
\hline & & $\begin{array}{l}\text { New formulation } \\
\quad \# 1\end{array}$ & 07/30/2009 & $\begin{array}{l}\text { New dosage form, } \\
\text { route, strength }\end{array}$ & $\begin{array}{c}\begin{array}{c}\text { Solution, inhalation, } \\
0.6 \mathrm{mg} / \mathrm{ml}\end{array} \\
\end{array}$ & & & None \\
\hline & & $\begin{array}{l}\text { New formulation } \\
\quad \# 2\end{array}$ & $12 / 20 / 2013$ & $\begin{array}{l}\text { New dosage form, } \\
\text { strength }\end{array}$ & $\begin{array}{c}\text { Tablet, extended release, } \\
0.125 \mathrm{mg} \text { base, } \\
0.25 \mathrm{mg} \text { base }\end{array}$ & & & None \\
\hline & & $\begin{array}{l}\text { New formulation } \\
\# 3\end{array}$ & $10 / 07 / 2016$ & New strength & Tablet, $5 \mathrm{mg}$ base & & & None \\
\hline \multirow{3}{*}{$\begin{array}{l}\text { Voriconazole } \\
\text { (Vfend) }\end{array}$} & \multirow[t]{3}{*}{ Fungal infections } & Reference & $05 / 24 / 2002$ & N/A & Tablet & & $05 / 24 / 2016$ & $04 / 22 / 2010$ \\
\hline & & $\begin{array}{l}\text { New formulation } \\
\# 1\end{array}$ & $05 / 24 / 2002$ & New dosage form & Injectable, IV & & & $05 / 30 / 2012$ \\
\hline & & $\begin{array}{l}\text { New formulation } \\
\# 2\end{array}$ & $12 / 19 / 2003$ & New dosage form & Suspension & & & $05 / 28 / 2013$ \\
\hline
\end{tabular}




\section{TABLE 1 Reference and New Formulation Products in Cohort, Listed by Product Portfolio (continued)}

\begin{tabular}{|c|c|c|c|c|c|c|c|c|}
\hline $\begin{array}{l}\text { Drug } \\
\text { Portfolio } \\
\end{array}$ & $\begin{array}{c}\text { Original } \\
\text { Indication }^{\mathrm{a}}\end{array}$ & Product Category & Approval & $\begin{array}{c}\text { Product Change } \\
\text { Category }\end{array}$ & $\begin{array}{c}\text { Product } \\
\text { Characteristics }\end{array}$ & Discontinued & $\begin{array}{l}\text { Key Patent } \\
\text { Expiration }\end{array}$ & $\begin{array}{c}\text { Date of First } \\
\text { Generic } \\
\text { Entry }\end{array}$ \\
\hline \multicolumn{9}{|c|}{ Portfolios without a new formulation product introduced during the study period } \\
\hline $\begin{array}{l}\text { Adefovir } \\
\text { (Hepsera) }\end{array}$ & Hepatitis B & Reference & $09 / 20 / 2002$ & N/A & Tablet & & 09/02/2014 & 08/29/2013 \\
\hline $\begin{array}{l}\text { Eletriptan } \\
\text { (Relpax) }\end{array}$ & Migraines & Reference & $12 / 26 / 2002$ & N/A & Tablet & & $12 / 26 / 2016$ & $06 / 16 / 2017$ \\
\hline $\begin{array}{l}\text { Eplerenone } \\
\text { (Inspra) }\end{array}$ & Hypertension & Reference & 09/27/2002 & N/A & Tablet & & $02 / 11 / 2008$ & $07 / 30 / 2008$ \\
\hline $\begin{array}{l}\text { Fulvestrant } \\
\text { (Faslodex) }\end{array}$ & Breast cancer & Reference & $04 / 25 / 2002$ & N/A & $\begin{array}{l}\text { Injectable, } \\
\text { intramuscular }\end{array}$ & & $12 / 11 / 2007$ & None \\
\hline $\begin{array}{l}\text { Icodextrin } \\
\text { (Extraneal) }\end{array}$ & Renal disease & Reference & $12 / 20 / 2002$ & N/A & $\begin{array}{c}\text { Solution, } \\
\text { intraperitoneal }\end{array}$ & & 08/09/2009 & None \\
\hline $\begin{array}{l}\text { Perflexane; } \\
\text { dimyristoyl } \\
\text { lecithin } \\
\text { (Imagent) }\end{array}$ & $\begin{array}{l}\text { Injectable } \\
\text { suspension } \\
\text { used for } \\
\text { echocardiograms }\end{array}$ & Reference & $05 / 31 / 2002$ & N/A & $\begin{array}{l}\text { Injectable, } \\
\text { intravenous }\end{array}$ & 2005 & $06 / 17 / 2014$ & None \\
\hline $\begin{array}{l}\text { Sodium } \\
\text { oxybate } \\
\text { (Xyrem) }\end{array}$ & $\begin{array}{l}\text { Cataplexy in } \\
\text { narcolepsy } \\
\text { patients }\end{array}$ & Reference & 07/17/2002 & N/A & Solution & & $07 / 04 / 2020$ & $01 / 17 / 2017$ \\
\hline $\begin{array}{l}\text { Tegaserod } \\
\text { maleate } \\
\text { (Zelnorm) }\end{array}$ & $\begin{array}{l}\text { Irritable bowel } \\
\text { syndrome }\end{array}$ & Reference & $07 / 24 / 2002$ & N/A & Tablet & 2007 & $04 / 26 / 2013$ & None \\
\hline
\end{tabular}

aAll 21 new formulation products included the original indication approved in 2002.

${ }^{b}$ According to notices in the Orange Book and Federal Register, these brand products were voluntarily withdrawn before a generic company entered the market. For aripiprazole (Abilify), select strengths were withdrawn in different years before generic entry for those equivalents.

IV=intravenous; $N / A=$ not applicable.

products overall (including those that garnered no additional time) was 1.2 years (median $=0, \mathrm{IQR}=0-2.1$ ).

\section{Product Lineage Maps}

Of the 9 product portfolios that included new formulation products, 6 experienced generic entry for the reference product during the study period. For 3 portfolios (atomoxetine, ezetimibe, and olmesartan), generic entry for all new formulation products occurred at approximately the same time as their respective reference products (see Figure 2, Panel A).

By contrast, the timing of generic entry was staggered for the other 3 drug portfolios (aripiprazole, oxaliplatin, and voriconazole), with generic entry occurring later for the new formulation products than for the reference products (Figure 2, Panel B). For aripiprazole, generic versions of the initial oral formulation entered the market in 2015, but generic versions of the injectable formulations were not yet available by the end of the study period. For the initial lower-dose formulation of oxaliplatin, generic versions became available in 2009, before the expiration of the key patent in 2017, while a generic version of the high-dose formulation became available 6.8 years later in 2016. For voriconazole, generic versions of the initial oral tablet formulation became available in 2010, before the expiration of the key patent in 2016, while generic versions of the injectable and oral suspension formulations became available as generics 2.1 years and 3.1 years later in 2012 and 2013, respectively.

\section{Discontinuations}

Three reference (18\%) and 5 new formulation (24\%) products were discontinued during the 15-year observation period (Table 1). These discontinuations all occurred before generic entry and less than 2 years before expiration of the reference product's exclusivity (Figure 2). In 6 cases, generic manufacturers then petitioned the FDA to confirm that the withdrawals were voluntary and later gained approval to introduce their versions to the market. Four discontinuations (ezetimibe oxaliplatin, and 2 new formulations of aripiprazole) occurred less than 2 years before generic entry. One such discontinuation was oxaliplatin's reference product, which left a period of approximately 1.7 years in which only new formulation products were available to patients and prescribers.

\section{Discussion}

Manufacturers of about half of the new small-molecule drugs approved in 2002 introduced new formulation products onto the market, usually within 5 years of reference product launch. In half of the multiproduct portfolios in which generic entry was observed, it occurred simultaneously across all products. For the other half, generic versions of reference products were approved before generic versions of new formulation products.

Other studies have reviewed patterns of incremental pharmaceutical innovation. ${ }^{23,25}$ Our findings complement these works by providing additional insights into the practice of small-molecule drug modification. New formulations tend to 
Notes: New formulation products were added progressively over time. The new formulations were approved an average of 3.6 years (median $=2.1, I Q R=1.7-2.5)$,

7.3 years (median $=2.1, I Q R=1.7-2.5$ ), 5.1 years (median $=5.4, I Q R=3.9-11.1$ ), and 8.8 years after the reference products, respectively, depending on whether they were first, second, or third new formulation products. The average market exclusivity periods declined from 12.2 years (median =14.5, IQR =9.4-14.7) for reference products to 8.8 years (median $=10.0, I Q R=0.6-12.8)$ for first new formulation products $(9 / 17,53 \%) ; 6.5$ years (median $=8.9 ; \mathrm{IQR}=3.8-9.3)$ for second new formulation products $(7 / 17,41 \%)$; and 6.0 years (median $=6.3, I Q R=3.5-8.6)$ for third new formulation products $(3 / 17,18 \%)$. The average additional market exclusivity garnered by new formulation products was 1.2 years (median $=0.0, I Q R=0.0-1.9$ ).

$I Q R=$ interquartile range.

be introduced shortly after approval, suggesting that they may be used to provide greater choices to patients seeking to take the drugs and to open treatment to patients unable to use the original formulation. Since the immediate postapproval period is when manufacturers can charge high prices and may have the least amount of competition, it makes economic sense to expand the population of patients eligible to take a drug as widely as possible by introducing new formulations. In this respect, our finding that new versions were developed for about half of the drugs in our cohort gives the impression that current market opportunities lead some manufacturers to be active in continuously improving their products, which may add value and convenience for patients.

New formulations can also help provide manufacturers with additional years of market exclusivity beyond when generic entry occurs for the reference product. This happened in a minority of cases and allowed the manufacturer to continue to exclusively sell a brand-name version of the new formulation after a generic version of the original had entered the market. For example, while the FDA approved a generic version of the original tablet formulation of aripiprazole in 2015, Otsuka maintained monopoly over the brand-name injectable formulation of the drug as of 2017, which requires less frequent administration and may be preferable to some patients with schizophrenia.

Numerous product lines in our sample were the subject of voluntary product discontinuations. ${ }^{26,27}$ The practice of introducing new versions of products and later discontinuing some of them during the exclusivity period can be disruptive to care. In 3 cases in our study, voluntary withdrawals occurred as generic entry loomed-a possible signal that the brand-name manufacturer was attempting to forestall generic entry through product hopping. For example, the voluntary discontinuation of the initial formulation of oxaliplatin forced patients and prescribers to switch to new formulations protected by later expiring patents and may have resulted in longer market exclusivity had a patent challenge not been successful. Such discontinuations should accordingly prompt scrutiny by the Federal Trade Commission, the federal regulatory agency that investigates unfair business practices. Congress could also consider passing legislation allowing generic entry to occur immediately after a manufacturer ends production on an FDA-approved 
FIGURE 2 Product Lineage Maps for Product Portfolios that Experienced Generic Entry

Panel A. Product Portfolios that Experienced Simultaneous Generic Entry ${ }^{a}$
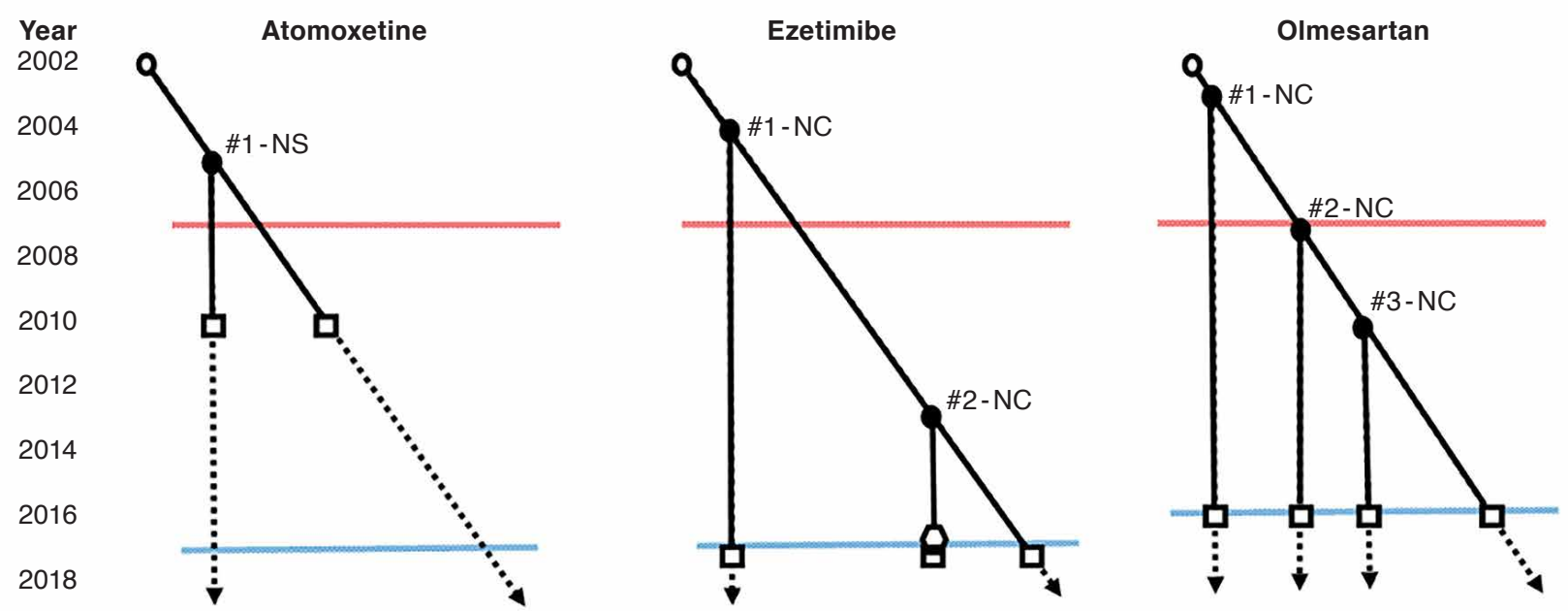

Year

2002

2004

2006

2008

2010

2012

2014

2016

2018

Panel B. Product Portfolios that Experienced Staggered Generic Entry ${ }^{b}$

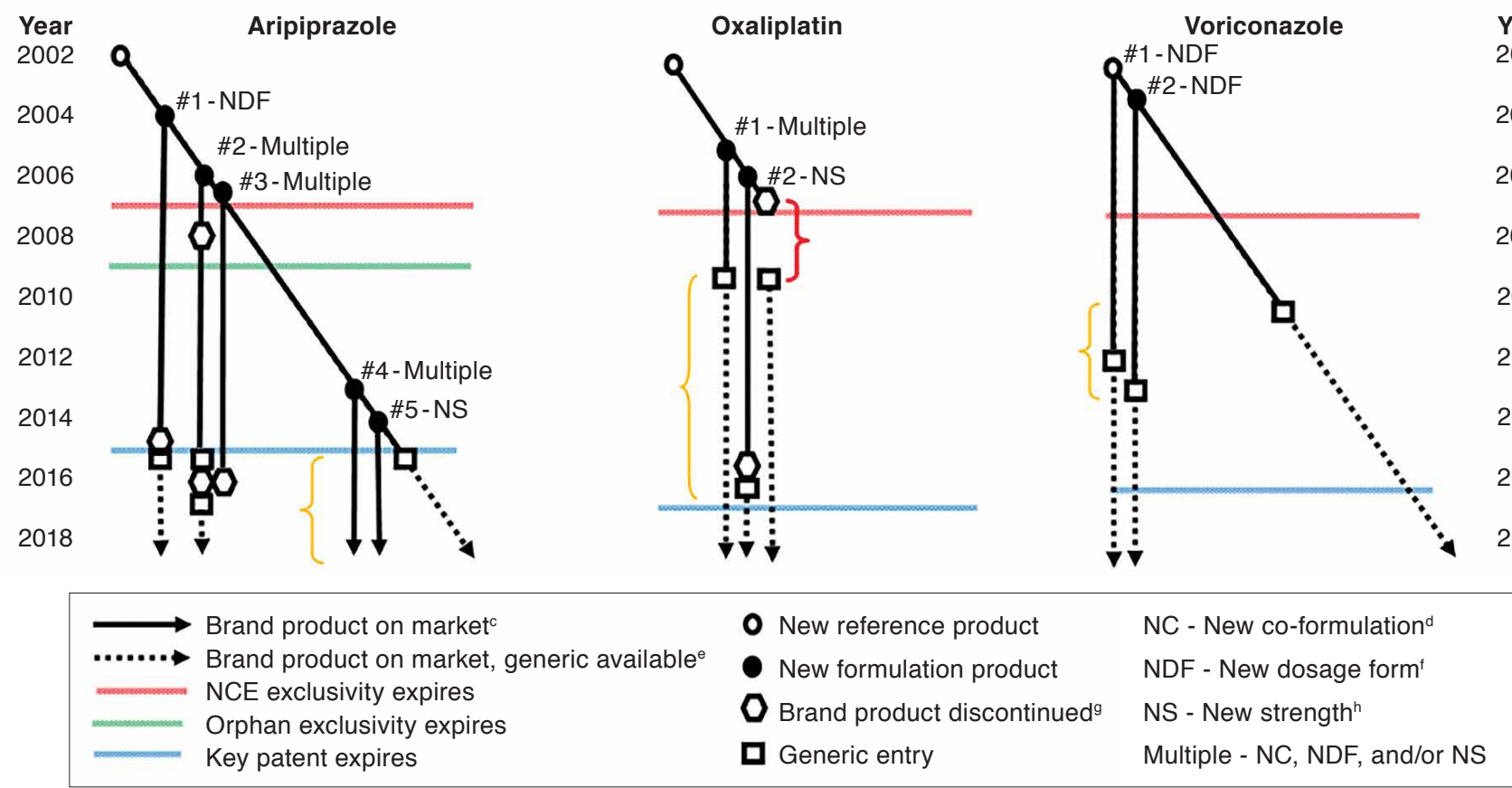

Notes: This figure shows the product lineage maps for the 6 product portfolios that experienced generic entry during the study period. The reference products are shown diagonally as trunks with each new formulation branching directly downward. The yellow brackets indicate the difference between the timing of generic entry on reference and new formulation products. The red bracket indicates the time in which the only version of the drug available was a new formulation product.

In this panel, the timing of generic entry was simultaneous across the entire portfolio in the cases of atomoxetine, ezetimibe, and olmesartan. No additional exclusivity time was garnered via new formulation products.

bIn this panel, generic entry was staggered by formulation in the cases of aripiprazole, oxaliplatin, and voriconazole.

cSolid lines indicate time segments in which brand-name products had exclusivity.

${ }^{d}$ New co-formulations are new combinations of the reference drug with another active ingredient.

eDotted lines indicate where a generic therapeutic equivalent of the brand name was available.

$f_{A}$ new dosage form is a change in the route of administration and/or its formulation (e.g., extended-release version).

gDiscontinuations are indicated by octagons in the line. Note that aripiprazole's second-level new formulation product had 4 strengths that were discontinued in 2 stagesthe $20 \mathrm{mg}$ and $30 \mathrm{mg}$ strengths were discontinued in 2008, and the $10 \mathrm{mg}$ and $15 \mathrm{mg}$ strengths were discontinued in 2016. Generic entry for the latter strengths occurred in 2015 and 2017, respectively.

$h_{A}$ new strength is strength not previously available (e.g., a double-strength version). 
brand-name version of a drug for nonsafety reasons, regardless whether a patent or regulatory exclusivity exists.

\section{Limitations}

In this investigation, we did not evaluate the comparative utility of the products. Further, our study was restricted to a single year of drug approvals and 15 years of follow-up time. It is possible that new formulations of the reference products in our sample will appear on the market in the future. Finally, our study did not control for market size. Generic manufacturers are more likely to challenge patents for more lucrative drugs, which can influence the timing of generic entry. ${ }^{28}$

\section{Conclusions}

We looked retrospectively at the market evolution of new formulations arising from a set of novel drugs. The patterns we found indicate that a considerable subset of these drugs were developed into new formulations, with the prospect of patient benefit, as well as prolonged consumption of costly brand-name products. If replicated in other cohorts of drug approvals, these results could help spur policymakers to reexamine these practices and install guardrails to ensure that sufficient incentives exist for reasonable formulation innovation, as well as timely entry of low-cost generic drugs.

\section{Authors}

REED F. BEALL, PhD, Program On Regulation, Therapeutics, And Law (PORTAL), and Division of Pharmacoepidemiology and Pharmacoeconomics, Brigham and Women's Hospitall Harvard Medical School, Boston, Massachusetts, and Department of Community Health Sciences, Cumming School of Medicine and O'Brien Institute for Public Health, University of Calgary, Canada. AARON S. KESSELHEIM, MD, JD, MPH, and AMEET SARPATWARI, JD, PhD, Program On Regulation, Therapeutics, And Law (PORTAL) and Division of Pharmacoepidemiology and Pharmacoeconomics, Brigham and Women's Hospital/Harvard Medical School, Boston, Massachusetts.

AUTHOR CORRESPONDENCE: Ameet Sarpatwari, JD, PhD, Department of Medicine, Brigham and Women's Hospital/Harvard Medical School, 1620 Tremont St., Ste. 3030, Boston, MA 02120. Tel.: 617.278.0930; E-mail: asarpatwari@bwh.harvard.edu.

\section{DISCLOSURES}

This work was funded by the Laura and John Arnold Foundation. Kesselheim and Sarpatwari also receive support from the Harvard-MIT Center for Regulatory Science and the Engelberg Foundation. Beall has nothing to disclose.

\section{REFERENCES}

1. Downing NS, Ross JS, Jackevicius CA, Krumholz HM. How Abbott's fenofibrate franchise avoided generic competition. Arch Intern Med. 2012;172(9):724-30. 2. Gellad WF, Choi P, Mizah M, Good CB, Kesselheim AS. Assessing the chiral switch: approval and use of single-enantiomer drugs, 2001 to 2011. Am J Manag Care. 2014;20(3):e90-97.

3. Kesselheim AS, Fischer MA, Avorn J. Extensions of intellectual property rights and delayed adoption of generic drugs: effects on medicaid spending. Health Aff (Millwood). 2006;25(6):1637-47.
4. Luo J, Kesselheim AS. Evolution of insulin patents and market exclusivities in the USA. Lancet Diabetes Endocrinol. 2015;3(11):835-37.

5. Beall RF, Nickerson JW, Kaplan WA, Attaran A. Is patent "evergreening" restricting access to medicine/device combination products? PLoS One. 2016;11(2):e0148939.

6. Vokinger KN, Kesselheim AS, Avorn J, Sarpatwari A. Strategies that delay market entry of generic drugs. JAMA Intern Med. 2017;177(11):1665-69.

7. U.S. Food and Drug Administration. Patents and exclusivity. FDA/CDER-SBIA Chronicles. May 19, 2015. Available at: https://www.fda.gov/downloads/drugs/ developmentapprovalprocess/smallbusinessassistance/ucm447307.pdf. Accessed December 29, 2018.

8. Capati VC, Kesselheim AS. Drug product life-cycle management as anticompetitive behavior: the case of memantine. J Manag Care Spec Pharm. 2016;(4):33944. Available at: https://www.jmcp.org/doi/10.18553/jmcp.2016.22.4.339. 9. Carrier MA. Pharmaceutical antitrust complexity. CPI Antitrust Chronicle. November 2014. Available at: https://ssrn.com/abstract $=2530169$. Accessed December 29, 2018.

10. Gilbert R. Not another drug! Antitrust for drug and other innovations Antitrust. 2015;30(1):38-45. Available at: https://papers.ssrn.com/sol3/papers cfm?abstract_id=2712398. Accessed December 29, 2018

11. Cheng J. An antitrust analysis of product hopping in the pharmaceutical industry. Colum L Rev. 2008;108(6):1471-515.

12. Carrier MA. A real-world analysis of pharmaceutical settlements: the missing dimension of product-hopping. Fla Law Rev. 2010;62:1009-36.

13. Royall MS, Johnson AE, McKenney JC. Antitrust scrutiny of pharmaceutical "product hopping." Antitrust. 2013;28(71):71-77.

14. Grabowski H, Long G, Mortimer R, Boyo A. Updated trends in US brandname and generic drug competition. J Med Econ. 2016;19(9):836-44.

15. Grabowski HG, Vernon JM. Effective patent life in pharmaceuticals. Int J Technol Manag. 2000;19(1-2):98-120.

16. Wang B, Liu J, Kesselheim AS. Variations in time of market exclusivity among top-selling prescription drugs in the United States. JAMA Intern Med. 2015; 175(4):635-37.

17. U.S. Food and Drug Administration, Center for Drug Evaluation and Research. List of licensed biological products with (1) reference product exclusivity and (2) biosimilarity or interchangeability evaluations to date. Available at: https://www.fda.gov/downloads/Drugs/DevelopmentApprovalProcess/ HowDrugsareDevelopedandApproved/ApprovalApplications/

TherapeuticBiologicApplications/Biosimilars/UCM560162.pdf. Accessed December 29, 2018.

18. U.S. Food and Drug Administration. Orange Book: Approved Drug Products with Therapeutic Equivalence Evaluations. Retrieved May 3, 2018. Available at: https://www.accessdata.fda.gov/scripts/cder/ob/default.cfm. Accessed December 29, 2018

19. U.S. Food and Drug Administration. Drugs@FDA: FDA approved drug products. Retrieved May 3, 2018. Available at: https://www.accessdata.fda.gov/scripts/ cder/daf/. Accessed December 29, 2018.

20. Kesselheim AS, Sinha MS, Avorn J. Determinants of market exclusivity for prescription drugs in the United States. JAMA Intern Med. 2017;177(11):1658-64. 21. U.S. Patent and Trade Office. Patent terms extended under 35 USC $\$ 156$. Available at: https://www.uspto.gov/patent/laws-and-regulations/patent-termextension/patent-terms-extended-under-35-usc-156. Accessed December 29, 2018.

22. Hemphill CS, Sampat BN. Evergreening, patent challenges, and effective market life in pharmaceuticals. J Health Econ. 2012;31(2):327-39.

23. Beall RF, Darrow JJ, Kesselheim AS. A method for approximating future entry of generic drugs. Value Health. 2018;21(12):1382-89

24. U.S. Food and Drug Administration. Paragraph IV patent certifications. December 18, 2018. Available at: https://www.fda.gov/downloads/ Drugs/Development ApprovalProcess/HowDrugsareDevelopedandApproved/ ApprovalApplications/AbbreviatedNewDrugApplicationANDAGenerics/ UCM293268.pdf. Accessed December 29, 2018.

25. Feldman R, Wang C. May your drug price be ever green. UC Hastings Research Paper No. 256. October 29, 2017. Revised June 13, 2018. Available at: https://ssrn.com/abstract=3061567. Accessed December 29, 2018.

26. Qureshi ZP, Seoane-Vazquez E, Rodriguez-Monguio R, Stevenson KB, Szeinbach SL. Market withdrawal of new molecular entities approved in the United States from 1980 to 2009. Pharmacoepidemiol Drug Saf. 2011;20(7):772-77. 27. Qureshi Z. Market discontinuation of pharmaceuticals in the United States [dissertation]. Columbus, OH: Ohio State University; 2009.

28. Grabowski HG, Kyle M. Generic competition and market exclusivity periods in pharmaceuticals. Manage Decis Econ. 2007;28(4-5):491-502. 